\title{
LEADERSHIP CRISIS IN NIGERIA: THEOLOGICAL STUDY OF JOHN 10:11-15
}

\author{
Mary Emilia Aboekwe* \\ http://dx.doi.org/10.4314/og.v15i1.7s
}

\begin{abstract}
The circumstance of every nation is determined by the quality and vision of her leaders. Since after independent, Nigeria has been so unfortunate not to have gotten competent, effective and purposeful leaders capable of turning her highly great natural potentials into real economic and political powers. Both leaders and the lead fail to identify the essential values that sustain various societies constituting the nation and infuse such values into the nation's social system. This incompetence has led to leadership crisis and has now clogged on its wheel of striving for development. It is this bad leadership and perhaps the poor handling of many ethnic groups in the country that have triggered the conflict and anxiety that have trailed quest for national integration since after independence. This paper therefore, using the periscope John 10:11-15 which deals with the parable of the Good Shepherd, examines the leadership qualities of Jesus Christ and recommends it to Nigerian leaders. It further examines the text to ascertain its theological implications. The study traces two kinds of leadership operated in Nigeria (military and civilian) since after independence. While emphasizing the need for moral education and constant value re-orientation as the means to surmount the Nigeria's leadership challenges, the study recommends among others, the urgent need for paradigm shift in our social system in order to restore value based Nigerian society that would directly translate to value based leadership.
\end{abstract}

Keywords: Leadership, Crisis, Education, Value

\section{Introduction}

For many, Nigeria is a failed country in all ramifications. Quite contradictory to a country richly blessed with huge human and natural resources. Those placed at the helm of affairs; whose duty it is to pilot the government has dragged the giant of Africa to the mud. Since after her independence, two forms of government have 
Ogirisi: a new journal of African studies vol. 15s 2019

been tasted vis; civilian to military, military civilian, yet none has advanced the living condition of the citizenry. Significantly, Nigeria is one of the countries in the world that is richly blessed with huge natural and human resources. Nigeria has existed for fifty-nine years with little or no record of socio-economic development. This ugly trend is not unconnected with poor leadership. It is logically unbelievable and appalling that despite the long years of independence, Nigeria the so called "giant" of Africa is still battling with the problem of good governance, hence wallowing in poverty. The caliber of leaders that have attained leadership position since independence had in one way or the other lacked vision, most of them have been engrossed with corruption and political bickering leading to the enthronement of maladministration and mismanagement of public resources, and consequently economic setback and abject poverty as nation's heritage.

Successive Nigerian governments have failed to translate Nigeria's human and natural resources into economic power that could lift Nigerians from unemployment, poverty and misery. Asaju and Akume (2012) observe that "the major reason for Nigeria's present predicament is lack of good purposeful leadership at the helm of affairs in the country." It is believed that this lack of good leadership started as early as from the time of independence and it has been the bane of the nation's underdevelopment. The cause of this set back is quite glaring that even a nonprofessional will at a glance, identify the cause. Achebe (1983) in his thought, believes that most problems in Nigeria are caused by lack of competent and effective leadership. The socio-economic and political development of any country depends largely on the ability of its leadership to facilitate, establish and sustain good governance. Nigeria has existed for fifty-nine years with little or no record of socio-economic development.

All over the nations of the world, especially in the developed countries, effective management and utilization of available resources to better the living condition of the people has been the pre-occupation of the government. They ensure that scarce resources i.e. human and material resources are effectively and judiciously galvanized, utilized and sustained to ensure the development of their areas. But this has not been the case in most developing countries including Nigeria. 


\section{Conceptual Framework Leadership}

The modern conception of leadership emphasizes not only the leader as an individual, but also the group he influences and joint results, which often determine particular changes in the internal and external environment of the organization. Leadership is a set of functions that cover at least three variables: the leader, his followers and the conditions dictated by the situation. Leadership is a plethora of combinations formed by these variables (Bahreinian et al., 2012, p. 101). Leadership involves a type of responsibility aimed at achieving particular ends by applying the available resources (human and material) and ensuring a cohesive and coherent organization in the process (Ololube, 2013). Ivancevich, Szilagyi and Wallace (1993), define Leadership as "the relationship between two or more people in which one attempts to influence the other toward the accomplishment of some goal or goals."

Leadership is arguably one of the most observed, yet least understood phenomena on earth (Burns, in Abbasialiya, 2010). Over time, researchers have proposed many different styles of leadership as there is no particular style of leadership that can be considered universal. Despite the many diverse styles of leadership, a good or effective leader inspires, motivates, and directs activities to help achieve group or organizational goals. Conversely, an ineffective leader does not contribute to organizational progress and can, in fact, detract from organizational goal accomplishment. For Robbins (1979), "leadership is the ability to influence a group towards the achievement of goals". According to Tannenbaumet all (1961) "Leadership is the interpersonal influence exercised in a situation, and directed, through the communication process, towards attainment of a specific goal or goals". The common characteristic that can be found in many of the definitions is the 'influence' exerted by the leader. That is, he tries to influence the behaviour of others in a specific direction.

\section{Good Shepherd}

Here, there is need to address two questions; (1) what are the qualities enveloped in the imagery of a shepherd which Jesus wants to apply to himself? To put it another way, what does a shepherd do 
for his sheep within the ancient Palestinian setting in which the parable is set? (2) What is the import of the definite article ó in ó

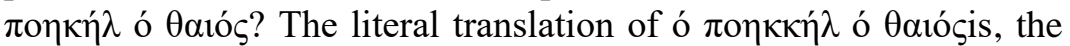
shepherd the good; i.e., the shepherd, the good one. Here, reference is made not to any shepherd at all, not to a counterfeit but to the good one as distinct from all other. So the import of the duplication of the definite article ' $o$ ' is to draw attention to the uniqueness of what Jesus stands for (the Good Shepherd) as opposed to bad ones.

\section{Leadership Crisis in Nigeria}

Since Nigeria gained independence in 1960, the country has been ruled by military and civilian leaders alike. Here, two regimes are considered: military regime and civilian regime. This paper focuses primarily in what authors have said about the subject matter rather than on the history of leadership in Nigeria. Finally, this paper is to see how leadership has failed in Nigeria since even in the midst of the nation's rich natural and human resources; Nigeria is ranked among the countries with high poverty rate.

\section{Leadership Crisis in Military Regime}

Jega (2007) asserts that the Nigerian military began its involvement with governance on January 15, 1966, when junior workers made a bid for power, which terminated the Tafawa Balewa's government and inadvertently brought General Aguiyi- Ironsi to power. For him, it is generally recognized that the involvement of the Nigerian military in governance has done more harm than good. Nigerian politicians who have assumed leadership positions in current democratic experiment seem to possess a disturbing inclination for squandering opportunities of democratic rebirth and regeneration.

Ifediba (2000) identifies military leadership in Nigeria with military dictatorship. For him, one of the basic features of military dictatorship is coup d'etat and suspension of the constitution which is often replaced with military decrees. For instance, after the annulment of June 12 elections in 1993 and in November the same year, when the interim government of Ernest Shonekan was overthrown by General Sani Abacha, Babangida's Minister of Defence, seized control of the government in a bloodless coup. The Abacha junta quickly imposed military administration on the entire 
Aboekwe: Leadership Crisis in Nigeria...

country, dissolving all elected governments and legislatures at the state and local levels and clamping down on dissent.

Describing the period of the regime of Abacha and making comparison, with Odey (2007) Sani Abacha ruled Nigeria from November 17, 1993 to June 8, 1998. For him, while Babangida was relatively more intelligent and quite interesting as a dictator who had the vicious capacity to make his victim believe that he had his best interest at heart even when he was strangling him, Abacha was crude and vicious. In the words of Odey (2007), Abacha was a "functional illiterate" but had a superlative degree of the type of debased military mind that was needed to plan and carry out the atrocities he committed against his country. For Odey (2007), in an effort by Abacha to make legitimate his rule, his regime announced plans to convene a National Constitution Conference to decide Nigeria's future form of government. Elections for the Constitutional Conference were hastily held in May 1994. Turnout was very low. In the same month, the National Democratic Coalition (NADECO) was formed to coordinate and focus the efforts of preDemocracy groups. On the anniversary of the annulled election, Abiola reasserted his claim to the presidency. Continuing his view, Odey (2007) stated that Abiola was arrested and imprisoned but in less than two weeks, on late June of 1993, the Constitutional Conference convened in Abuja, triggering off new protests, more arrests, and a debilitating strike by oil workers. The strike, which seriously reduced oil exports and paralyzed the domestic economy, was joined by university and bank employees. In early September, the strike was finally broken by the government. No wonder, Ifedibia (2003) considers the military incursion into administration of Nigeria as a deviation as well as a tragedy. In this, one can say that the military is the problem. The military took up a job they are most unqualified to do, a job which negates their role as a professional defense unit.

No wonder then Ofuebe (2005) laments the absence of good governance in the country after the many years of military intervention. In his view, civilian leaders have also perceived political leadership as an ample opportunity to accumulate money, thus the intense struggle to capture state power which they see as the most pliable strategy of becoming rich. Like Ifediba (2003), Ofuebe (2005) is critical of military leaders who get more corrupt and looted the national treasury much more than their predecessors whom they 
overthrew on the ground of corruption. He singles out Ibrahim Babaginda and Sani Abacha as the worst examples of corrupt leaders of military regimes in the country.

In his critique of military leadership in the country, Amaucheazi (1980) is not as damning as others mentioned above. In his view, even while in power, the army in Nigeria has not been as autocratic as in many other countries, but had rather from the start involved the civilians in decision-making and policy implementation. Jega (1996) however opines that the impact of prolonged military rule on Nigeria has not been consequential to the present crisis in the country. We must however acknowledge the difference in events and time between the 1980 of Amaucheazi's and the 1996 of Attahiru's here. Amaucheazi's 1980 was not only a time when civilians were in power but just after what appeared to be a humane military regime handed over power in strict compliance with the 1979 timetable it set by 1976 when it came into power after the overthrow of Murtala Mohammed.

The rule of law suffered much under the military, the Oputa Panel Report holds. The courts which form the citizen's last line of defense were not allowed to perform such duty. The military by suspending the fundamental rights provision of the Constitution and by its various decrees containing ouster clauses emasculated the courts and turned them into toothless bulldogs. During military dictatorship, the courts found it difficult to perform their statutory function of upholding the fundamental human rights of the citizens. Executive lawlessness and disregard for the rule of law became the order of the day. For Eregha (2005), one important feature of the leadership during the military regime is flagrant violation of human rights and judicial orders. They have no respect of law and the constitution which is the supreme authority of a state. Now, let us examine how Nigeria fared during Civilian administration.

\section{Leadership Crisis in Civilian Regimes}

Achebe (1983) argues that the trouble with Nigeria is simply and squarely a failure of leadership. The Nigerian problem is the unwillingness or inability of its leaders to rise to their responsibility, to the challenge of personal example which is the hallmarks of true leadership. The challenge of personal example is in the thought of Achebe of great importance but unfortunately it has not been so. 
Aboekwe: Leadership Crisis in Nigeria...

Okolo (1994) agrees with Achebe that Nigeria has a problem with leadership and insists that there can be no serious change in the country unless it occurs in the leadership. For him, if people see their political leaders as little more than robbers of the state, what prevents them from developing the same instinct in their lives? The burden of translating dreams of true progress and independence to reality lies on the Nigerian leaders. This is development, he holds.

In his view, Okwueze (2004) the term development is from the word, develop. For him, whenever the term development is used the general tendency is to think about growth, increase usually in infrastructure. In other words, when there is no befitting infrastructure in place in any country as the case with Nigeria, there is no development. That is to suggest that the concept of development must be necessarily related to concrete material things. He argues that although many people are still holding this view, that a number of others have discovered that it is not only erroneous but also misleading. He concludes however, that the matter is not helped either by the unchecked use of the words: underdeveloped, undeveloped, developing and developed.

For Achunike (2004) development is about people and steady improvement of their lives. In the opinion of Ekwunife (2007), to develop is to grow. Nigeria cannot be said to be growing in spite of the democratic governance in practice. There are problems. Similarly, Dike (2003) traces the problems in the country to the political leadership. He opines that the forbearers of Nigeria were entangled in tribal and ethnic issues and therefore could not lay a solid socio-political and economic foundation for the nation. Their successors did not fare any better. He believes that Nigerian political leaders are not working for the welfare of the country. Nigeria needs effective, self-critical, visionary and dynamic leaders who can put in place, structures and reforms that will strengthen the rule of law, support true democracy, promote greater accountability and transparency.

Onuigbo (2001) opines that a democratic nation vouches for economic stability and most importantly cares for the security of the workers. Nigeria is not here either. For him, it would seem that Nigerian leaders do not know precisely what it entails to be a democratic nation. He holds that democracy has neither double meaning nor alternative. Once it is democracy it remains so and 
anything outside government of the people under the regime of universal suffrage should be given another title but not democracy. He regrets that Nigerian's own democratic tenets are different due to a myriad of problems she created for herself.

Wilmot (2006) in one of his critical essays takes a look at the political leadership of Nigeria in the first republic, the military and the post-military civilian leadership alike. He maintains that the country's political leadership is collectively responsible for the widespread poverty and the growing gap between the rich and the poor among the citizenry. He gives the hardest knock to the military and their civilian successors and paints a gloomy picture of the future. He is of the opinion that the greatest condemnation of the military is the comparison of Nigerian leaders before and after 1966. Izukanne (2003) corroborates the view that the problems facing Nigeria can be traced essentially to the problem of leadership. He believes that Nigeria's underdevelopment is basically due to the criminal dishonesty of its leadership.

Okwueze (2000) believes strongly that leadership is a sacrifice and for service but it is not so in the Nigerian society today. For him, Nigerian leaders of today are those who expect the led to serve them and make sacrifices to enable them remain comfortable. He continues to see Nigeria as a society where the President would rather pay millions of Naira to procure a new presidential jet than repair dilapidated roads that have become death traps for the led. For him, it is a society where the legislature prefers to be paid N5million as furniture allowance rather than insist on the provision of shelter of any kind for the led. The led are told to be patient and make sacrifices to enable the leader travel in the comfort of the world's latest presidential jets. He opines that this is a society where a Governor refuses to give his people drinkable water only because he is amassing wealth for his campaign for a second tenure in office. The legislatures like to be settled rather than have certain social amenities located amongst the people he represents.

\section{Leadership Crisis in Nigeria: Theological Implication of John 10: 11-15}

The Good Shepherd discourse in John is a self-revelation of the identity of Jesus as the Good Shepherd. By proclaiming "I am the Good Shepherd", Jesus shows that Yahweh, the God of Israel is 
Aboekwe: Leadership Crisis in Nigeria...

present in him to save his own (verse 14) and care for them as a Good Shepherd defends and cares for his sheep. With divine authority, his words and actions are the words and actions of God which are powerful and worthy of belief. The Good Shepherd is known by the fact that he defends the sheep with his life while the hireling flees because he is only interested in his wages and not the welfare of the sheep. The Good Shepherd discourse is a revelation of God's love and care for his people. It is the consolation of all the marginalized and those living in poverty including those suffering from religious and political hirelings. The Good Shepherd leaves a message of hope.

Revelation is not the end in itself. Okwumuo (2007) holds that when God revealed himself to Moses, it was to go and deliver the Israelites from Egypt. When also the angel of the Lord appeared to Gideon at the threshing floor, he was asked to deliver the Israelites from the Medianites (Judges 6:11-36). When the angel of the Lord revealed himself to the mother of Sampson, the purpose was to instruct her to avoid wine or strong drink in view of the child who was to be born (Judges 13:1-7). In the same vein the political leaders who before the elections tell us that God has revealed to them that they should contest should also live by that revelation when they win though through a free, fair and credible election. Because the Good Shepherd discourse is an invitation as well as a challenge for leaders to lay down their lives for their brothers and sisters. To this end they need to enter into a loving relationship with God the Father through the Son. In this consists eternal life which for John is present here and now on earth.

The Good Shepherd discourse shows that life can never be saved except by laying it down for others. The world history has shown that those leaders who tried to lay down their life are still been remembered evergreen. Mahatma Ghandi of India, Martin Luther King Jr. of the United States, Mother Theresa of Calcutta, Oscar Romero from Latin America, Julius Nyerere of Tanzania and Nelson Mandela of South Africa are good examples. They embraced the ideal of the Good Shepherd and now are standing in sharp contrast with the hirelings like Idi-Amin of Uganda, Mobutu Seseseko of Zaire, Papa Doc of Haiti, Sani Abacha of Nigeria and other political leaders who loot the national treasury with impunity. The same is the case with religious leaders who feed themselves 
Ogirisi: a new journal of African studies vol. 15s 2019

rather than the sheep. The hirelings are already dead but the good shepherds go on living in the minds of people and on the sands of history.

According to Okwueze (2003), one of the most significant lessons that Jesus taught is that leadership is for service and nothing else. He insisted that there must be a distinction between the attitude of a Christian who is a leader and that of the non-Christian. Leaders, properly speaking, are therefore those who have sacrificed their own comfort so that others may have comfort. That is why Jesus refers to himself as one who has given his life as a ransom for many. Jesus stands out as the best example of such a leader whose desire and purpose is to, as long as it is necessary, discomfort Himself in order to bring comfort to his subjects. Summarizing, Okwueze is of the opinion that in his preaching on the good shepherd Jesus reiterated the concept of sacrifice as the cardinal virtue of any who is put in a position of leadership. He emphasized that a good shepherd is one who lays down his life because of his flock. In so doing, the good shepherd has given his own life as a ransom for his flock.

The ability and willingness to lay down one's life for the sheep is the distinguishing mark of the good shepherd (vv 11, 14, 18). Life is a primary value in the sense that it is only when one is alive that one can think of accomplishing any other thing. These show that there should be no limit to the nature and intensity of sacrifice which may be demanded of a leader. The Good Shepherd knows his own and his own knows him (v. 14). Any shepherd who is ignorant of his sheep and their problems cannot be a good shepherd. Part of the crisis of leadership in Nigeria arises from the fact that there is no meeting point between the leaders and the people, for they belong to different classes and different world altogether. Generally, the leaders are super-rich while the people wallow in abject poverty. They live in sprawling mansions, eat the best type of food drink, the best type of wine, are clad in most expensive clothes like dives and are chauffeur-driven in most expensive cars; while the average Nigerian has problem with the basic necessities of life like food, shelter and clothing.

However, consider in a flash how Nigerian leaders protect themselves since the country has been experiencing kidnapping. They move about with Police escorts thereby limiting the protection of the ordinary citizen along the streets. Political leadership 
Aboekwe: Leadership Crisis in Nigeria...

according to the Good Shepherd discourse is not about personal gain. Furthermore, it has nothing to do with looting the public treasury, embezzlement and corruption as well as sponsored assassination as we are experiencing too. Since the political power need not be sought at all cost, electoral malpractices are unnecessary. It is a challenge to sacrifice oneself for the good of others.

\section{Conclusion and Recommendation}

The Good Shepherd Discourse in John 10:11-15 occurred in the context of pretensions to leadership on the part of Jewish authorities of Israel especially the Pharisees who felt they had their sight-seeing but were in fact blind without knowing it. Their blindness was manifested in the high-handed manner in which they treated the man born blind by expelling him from the synagogue. The people were snubbed and held in contempt by their religious leaders and by extension their political leaders whose interest they represent (9:22, 34, 12:42). Against this background, Jesus reveals himself as the Good Shepherd who lays down his life for his sheep unlike the hireling who flees at the sight of the wolf (vv. 11-12). He also shows the intimate relationship which exists between him and the people and between him and the Father (vv. 14-15). As the Good Shepherd, Yahweh the God of Israel is present in the person of Christ to enlighten and save the people he calls -my own (v. 14). As the ideal shepherd, Jesus not only sums up all the qualities of a good shepherd but lays down his life for the sheep (vv. 15, 18). Moreover, Jesus brings them into union with the Father through his union with the sheep.

The Good Shepherd comes in sharp contrast with Nigerian leaders who are but hirelings. The work has also made effort to establish how governance in Nigeria has not been working since the country gained her independence in 1960 . However, there are signs of recovery if certain aspects of enthroning democracy and good governance are made to function properly.

This leadership failure in Nigeria is quite unfortunate and is heart breaking. Based on the discussions in this study, the following recommendations are made viz: 
Ogirisi: a new journal of African studies vol. 15s 2019

- There is need for massive education which will focus primarily on re-orientation of the ethical values among youths.

- There is need to sanitize the selective process of our leaders.

- Nigerian leaders should take programs which will massively change their mindsets.

*Mary Emilia Aboekwe, Chukwuemeka Odumegwu Ojukwu

University, Igbariam-Anambra State,Nigeria,emiliachy@gmail.com 
Aboekwe: Leadership Crisis in Nigeria...

\section{References}

Abbasialiya, A. (2010). The Concept of Leadership. Retrieved August 11, 2019, from http://expertscolumn.com/ content/concept-leadership.

Achebe, C. (1983). The trouble with Nigeria. Enugu: Fourth Dimension.

Achunike, H. (2004). Developing the Nigerian Nation through Justice, Development and Peace Commission of the Catholic Church in Religion and Societal Development: Contemporary Nigerian Perspectives. Lagos: Merit International.

Amucheazi, E. (1980). Colonial Heritage and the Problems of National Development in Reading in Soil Sciences: Issues in National Development(ed). Enugu: Fourth Dimension.

Asaju, K., \& Akume, A. (2012). Vision 20:2020: Realities and Challenges. Journal of Research in National Development, 10(2), 32-40

Bahreinian, M., Ali, M., Soltani, F. (2012), The relationship between personality type and leadership style of managers: a case study, Mustang Journal of Business \& Ethics, Edmond, Vol. 3, pp. 94-111, ISSN 1949-172.

Dike, V. (2003). Nigeria and the Politics of Unreason: A Study of the Obasanjo Regime. London: Adoris\& Abbey.

Ekwunife, A. (2007) What Will Be, Will Be: Why Pray? Prayer in the Three Traditions of Nigeria: Lagos: Priceless.

Eregha, E. \&Agbro, E. (2005). Elements of Government and Politics of African States. Benin City: Eregha.

Ifediba, U. (2003). Military Dictatorship: The Impact of a Tragedy. (Ist ed.) Ekwulobia: Godamset.

Ivancevich, Szilagyi and Wallace, (1993). Organisation behaviour and performance, (Adopted from Dr. M.J. Mathew, Organisation: Theory and Behaviour, Jaipur: RBSA Publishers.

Izukanne, M. (2003). Nigeria's Quest for Democracy 1960-2003: A Mirage. Nsukka: Afro - Orbis Publishing Co.

Jega, A. (2007). Democracy, Good Governance and Development in Nigeria. Ibadan: Spectrum Books Limited. 
Ogirisi: a new journal of African studies vol. 15s 2019

Jega, A. (1996). The Political Economy of Nigerian Federalism: 1960-1995. Abuja: National Council on Intergovernmental Relations.

Koontz O' D. (1984). Management. New York: McGraw-Hill International Book Company.

Keith D. (1975). Human Behaviour at work.New Delhi:Tata McGraw-Hill.

Odey, J. (2007). Another madness called election 2007. (Vol.1). Enugu: Snaap.

Ofoebe, C. (2005). Scramble for Nigeria. Enugu: New Generation Books.

Okwueze, M. (2004). Religion and Societal Development: Contemporary Nigerian Perspective (ed). Lagos: Merit International.

Okwumuo, C. (2007). The good shepherd discourse in John 10: 1115 And The Crisis of Political Leadership in Nigeria. Port Harcourt: CIWA STL.

Okolo, B. (1994) Squandermania Mentality: Reflection on Nigerian Culture. Nsukka: University Trust.

Ololube, N. P. (2013). Educational Management, Planning and Supervision: Model for Effective Implementation. Owerri: SpringField.

Onuigbo, S. (2001). Democracy in praxis and the Nigerian situation. Bigard Jubilee Essays.Valerian Okeke (ed.). Nsukka: Fulladu.

Paul Hersey and K.H. Blanchard, (1977). Management of organisational behaviour. New Jersey: Engle wood Cliffs, Prentice Hall.

Robert Tannenbaum, R. Weschier and Fred Massarik, (1961). Leadership and Organisation: A Behavioural Science approach.New York: McGraw-Hill Book Co., Inc..

Robbins, S.P. (1979). Organisational Behaviour: Concepts and Controversies. New Jersey:Engle wood cliffs, Prentice Hall.

Wilmot, P. (2006). Nigeria in 2036 in The News (Vol. 27 No. 24). 25th December 2006. 